\title{
Duygu ve Düşüncelere Saygı Değerinin Etkinlik Temelli Öğretiminin Saygı Eğilimine Etkisi*
}

\section{The Impact of Activity-Based Teaching of the Value of Respecting the Feelings and Opinions of Others on the Students' Inclination to Respect**}

\author{
Yasemin ALTUNSOY, Doktora Öğrencisi. \\ Trabzon Üniversitesi Lisansüstü Eğitim Enstitüsü, Trabzon / Türkiye \\ y.kinalioglu_61@hotmail.com \\ https:// orcid.org/0000-0001-6969-0853
}

Zeynep BAŞCI NAMLI, Sorumlu Yazar, Dr. Öğr. Üyesi Atatürk Üniversitesi Kazım Karabekir Eğitim Fakültesi, Erzurum / Türkiye zbasci@atauni.edu.tr

https://orcid.org/0000-0003-2865-5976

ISSN: 1303-880X

e-ISSN: 2667-7504

http://ded.dem.org.tr

Makale Türü / Article Type:

Araştırma Makalesi / Research Article

Geliş Tarihi / Received Date: 06.07.2021

Kabul Tarihi / Accepted Date: 23.10.2021

Yayın Tarihi / Published Date: 25.12.2021

Tr/En: $\operatorname{Tr}$

Intihal / Plagiarism: Bu makale, en az iki hakem tarafindan incelendi ve intihal içermediği teyit edildi. / This article has been reviewed by at least two referees and scanned via a plagiarism software.
Atıf/Citation: Altunsoy, Y. \& Başçı Naml, Z. (2021). Duygu ve düşüncelere sayg1 değerinin etkinlik temelli öğretiminin sayg1 eğilimine etkisi. Değerler Ĕ̈itimi Dergisi, 19 (42), s.305-335

https://doi.org/10.34234/ded.959194

* Bu çalışma ilk yazarın yüksek lisans tezinden üretilmiştir ve 7-9 Kasım 2019 tarihlerinde 8. Uluslararası Sosyal Bilgiler Eğitimi Sempozyumu (ISSSE-USBES 2019)' nda sözlü bildiri olarak sunulmuştur.

**This study was produced from the first author's master's thesis. It was presented as an oral presentation at the 8th International Social Studies Education Symposium (ISSSE-USBES 2019) on 7-9 November 2019. 
Öz: Bu çalışmanın amacı, dördüncü sınıf Sosyal Bilgiler Dersi Öğretim Programı'nda yer alan "duygu ve düşüncelere saygı" değerinin etkinlik temelli öğretiminin öğrencilerin saygılı olma eğilimine etkisini araştırmaktır. Karma araştırma yaklaşımlarından gömülü desenin kullanıldığı çalışma, 35 ilkokul dördüncü sınıf öğrencisinin (deney grubu, $n=17$; kontrol grubu, $n=18$ ) katılımıyla gerçekleştirilmiştir. Uygulama aşamasında; deney grubunda duygu ve düşüncelere sayg1 değerini içeren çeşitli etkinlikler kullanılırken; kontrol grubunda ise mevcut program çerçevesinde sosyal bilgiler ders kitabı üzerinden yürütülmüştür. Çalışmada veri toplama aracı olarak Saygılı Olma Eğilimi Ölçeği ve Yarı Yapılandırılmış Görüşme Formu kullanılmıştır. Uygulama sonucunda, deney grubu öğrencilerinin sayg1 eğilimi düzeylerinde artış meydana geldiği görülmüştür. Öğrencilerin sayg1 değerine ilişkin görüşleri incelendiğinde; etkinlikler yoluyla saygı değerini kazanmaya daha istekli oldukları, bireysel ve toplumsal açıdan değerlerin önemini anlama ve saygılı olma bilinçlerinde bir farkındalık meydana geldiği tespit edilmiştir.

Anahtar Kelimeler: Değer Eğitimi, Duygu ve Düşüncelere Sayg1, Sayg1 Eğilimi, Etkinlik Temelli Öğretim.

$\&$

Abstract: The aim of this study is to investigate the activity-based teaching of the value of "respecting others' thoughts and feelings", which is included in the fourth grade Social Studies Curriculum, in terms of its impact on students' inclination to respect. The study employed an embedded research design, from among the mixed research approaches, and was conducted with the participation of 35 fourth grade students studying at primary school (experimental group, $n=17$; control group, $n=18$ ). In the implementation phase, various activities were conducted in the experimental group in such a way as to involve the value of respecting others' thoughts and feelings, whereas in the control group, it was carried out on the Social Studies textbook within the framework of the current program. In the study, The Scale of Inclination to Respect" and "Semi-structured Interview Forms" were used as data collection tools. At the end of the study, it was found that the level of students' inclination towards being respectful increased in the experimental group. Moreover, the students' views indicated that they were more willing to gain the value of respect through activities, and that they became more aware of the importance of recognizing the values in terms of individual and social aspects as well as of being respectful of them. 
Keywords: Value Education, Respecting Others' Thoughts and Feelings, Inclination to Respect, Activity-Based Teaching.

(The Extended Abstract is at the end of the article)

\section{Giriş}

Bir toplumun sosyokültürel birikimini meydana getiren en önemli parçalar, o toplumun bireyleri tarafindan oluşturulmaktadır (Özensel, 2003). Okullar, bu birikimi oluşturacak bireylerin uygun bilgi, beceri ve değerler ile yetişmesini ve gelişmesini amaçlayan kurumlardır. Günümüzde okullar, öğrencilere akademik başarıya ulaşmalarının yanında onlara yetişmiş ve kendini gerçekleştirmiş bireyler olarak yaşamlarını sürdürme becerilerini kazandırabilmeyi ve onları "iyi insan" olarak yetiştirmeyi hedeflemektedir. İyi insan yetiştirme çalışmalarında ise değerler, önemli bir rol oynamaktadır. Özellikle de ilkokulda değerler eğitimi çalışmalarının etkili bir şekilde uygulanabilmesi, öğrencilerin ileriki yaşamları için sağlıklı bir kişilik oluşturmalarına yardımcı olmaktadır (Albayrak, 2015). Bu değerlerden biri olan "saygı", öğrencilerin kazanması gerekli görülen temel bir değer konumundadır. Sayg1; birçok bilgiyi, sezgiyi ve değeri bünyesinde barındıran ve alt yapı oluşturan temel bir değerdir (Loomans ve Loomans, 2005). Nitekim öğrencilerin saygılı olma değerinin ve neden farklı düşüncelere saygılı olmaları gerektiğinin bilincine varabilmeleri, onların saygı ile birlikte farklı değerleri de içselleştirebilme ve kişiliklerinin bir bütün halinde gelişebilme süreçlerine olumlu yönde etki edebilir. Saygı değerine ait alt kavramlardan birini "duygu ve düşüncelere saygı" oluşturur (MEB Sosyal Bilgiler Dersi Öğretim Program1, 2017). Farklı duygu ve düşüncelere sayg1 değeri bünyesinde adalet, barış, empati ve insan haklarına saygı değerlerini de barındırır. Başka bir deyişle insanların birlikte huzur ve barış içinde yaşamaları, farklı görüşlerin rahat ve objektif bir biçimde ifade edilebilmesi, herkesin farklı düşüncelere ve hislere sahip olabileceğini kabullenebilme durumu; duygulara ve düşüncelere saygı duyabilen insanların olduğu ortamlarda var olabilir (Balcı ve Yelken, 2013). Bireylerin farklı duygulara ve düşüncelere saygıyla bakabilmeleri; bu değerin kazandırılması hedeflenen öğrencilerin okul öncesi dönemden başlayarak, öğretim programlarında duygu ve düşüncelere saygı değeri ile karşılaşabilmeleri ve öğrencilerin değer kazanma süreci içinde aktif bir şekilde yer alabilmeleriyle mümkün olabilir.

Saygı değerine ilişkin alanyazın incelemesinde, çalışmaların özellikle özsaygı, farklılıklara saygı ve Türk büyüklerine saygı değerlerine yönelik araştırma- 
lar etrafında şekillendiği görülmüştür (Çatlak, 2017; Ekmişoğlu, 2007; Eren, 2015; Gümüş; 2016; Güven, 2012; Kacar, 2018; Öztürk, 2018; Topcubaş1, 2015; Yıldırımçakar, 2018). Bununla birlikte ilkokul ve özellikle de dördüncü sınıf seviyesinde yapılan çalışmalarda, duygu ve düşüncelere saygı değerine ilişkin sınırlı sayıda çalışmanın olduğu görülmüştür. Oysa duygu ve düşüncelere sayg1 duyulan ortamlar, insanların demokratikleşme süreçlerinde önemli bir yol aldıkları ve insan hakları standartlarının yükseldiği ortamlardır. İnsanların birlikte huzur ve barış içinde yaşamaları, farklı görüşlerin rahat ve objektif bir biçimde sunulması, herkesin farklı düşüncelere ve hislere sahip olduğunu kabullenme durumu; duygulara ve düşüncelere saygı duyan insanların olduğu ortamlarda mevcuttur. Ayrıca dördüncü sınıf öğretmenleri üzerinde yapılan bir çalışma, öğretmenlerin en çok önem verdikleri değerlerden birinin "duygu ve düşüncelere saygı" değeri olduğunu ortaya koymuştur (Balc1 ve Yelken, 2013). Dolayısıyla farklı duygu ve düşüncelere saygı ile bakmanın; insanın, toplumun ve devletlerin demokratik kimlikleri üzerinde bu denli etkili olması, bu değerin öne alındığı bir çalışmayı gerekli kılmaktadır.

Öğrencilere, açık veya örtük program dâhilinde değer kazandırabilme sürecinde yararlanılabilecek bazı yaklaşımlar bulunmaktadır. Bu yaklaşımlar, geleneksel veya öğrenci merkezli yaklaşımları da içerebilmektedir. Ancak ortaya çıkan yeni yaklaşımlar; her ders ve kazanımda olduğu gibi, değerleri kazandırma sürecinde de öğrenciyi merkeze alabilecek etkinlikler ile örülü bir düzenlemenin gerekliliğini ortaya koymaktadır (Özden, 2005). 2005 y1lında yenilenen öğretim programları ile kavram ve becerilerinin öğretiminde olduğu gibi değer kazandırma sürecinde de kazandırılması hedeflenen değerler ile ilgili etkinliklerin hazırlanıp planlamalarının önceden yapıldığı, öğrencinin yaparak yaşayarak öğrenme firsatı bulduğu ve yapılan çalışmalarda aktif rol aldığı bir öğretim süreci geçirebilmesi esastır (Aydın, 2010). Öğrencinin aktif katılımını esas alan ve öğrencinin merkezde olduğu etkinlik temelli öğretim süreci; öğrencilerin çeşitli etkinlikler ile bilgiye ulaşmasını amaçlayan ve bilgiye ulaşmada aktif konumda olduğu, gerçekleştirilen etkinlikler sonunda öğrencilerin motive olduğu ve eğitsel doyum yaşadığı yapılandırmacı bir öğrenme-öğretme sürecidir (Kalem ve Fer, 2003). Etkinlik temelli değer kazandırma sürecinde, öğrenciyi merkeze alacak farklı etkinliklerden faydalanılması, her öğrencinin ayrı bir birey olarak kendi değer yargılarını ve değer sistemlerini oluşturması sürecinde etkili olabilir. Ayrıca farklı etkinliklerle karşılaşan öğrencilerin değer kazanma sürecinde aktif ve motive olmaları ile eğlenceli bir öğretim süreci geçirmeleri sağlanır (Akın, 2007). Öğrencilere saygı değerini kazandırabilmek ve bu değere yönelik 
farkındalık oluşturabilmek amacıyla çeşitli yaklaşım ve yöntemler üzerinde çalış1lmıştır. Değer kazandırma sürecinde; çokkültürlü eğitim (Öztürk, 2018) ve karakter eğitimi (Demir, 2008), storyline (Çatlak, 2017) ve yaratıcı drama yöntemi (Barcın, 2018), filmlerin etkisi (Kavun, 2018), tarihi konular ile (Gülmüş, 2015) ve edebi metinlerin içerdikleri değerler (Özkan, 2017) ve farklılıklara saygı (Topcubaşı, 2015; Polat ve Yıldız, 2018) programlarından faydalanmanın değer kazandırmaya ilişkin çalışmalarla karşılaşılmıştır. Ayrıca etkinlik temelli öğretimin öğrencilerin akademik başarıları ile birlikte, tutum ve davranışlarına da etki ettiğine dair sonuçlara ulaşılmıştır (Aktepe, 2010; Kösterelioğlu, Bayar ve Kösterelioğlu, 2014). Aktepe (2010), yaptığı araştırmada yardımseverlik değerinin etkinlik temelli öğretim yaklaşımı ile kazandırılmasının, öğrencilerin yardımseverlik değerine dair farkındalıklarını artırdığını ortaya koymuştur. Yine gerçekleştirilen başka bir çalışma ise; etkinlikler ile örülü bir eğitim sürecinin öğrencilerin akademik başarıları ile iletişim becerilerine ve farklılıklara sayg1 düzeylerine olumlu katkı sağladığı sonucuna ulaşmıştır (Kösterelioğlu, Bayar ve Kösterelioğlu, 2014). Nitekim farklılıklara saygı değeri, duygu ve düşüncelere saygı değeri ile oldukça ilişkilidir.

Duygu ve düşüncelere saygı değerinin etkinlikler yoluyla kazandırılmasına dair bir çalışmanın bulunmayışı ve yapılan çalışmalarda, etkinlikler ile öğretimin farklı değerler ve tutumların kazanımına olumlu etki ettiğinin görülmesinden dolayı, dördüncü sınıf Sosyal Bilgiler Dersi Öğretim Programı'nda yer alan “duygu ve düşüncelere saygı" değerinin etkinlikler yoluyla kazandırılmasının öğrencilerin saygılı olma eğilimine etkisinin incelemesi amaçlanmıştır. Bu genel amaca bağlı olarak aşağıdaki sorulara cevap aranmıştır:

- Kontrol grubu öğrencilerinin saygılı olma eğilimleri ön test ve son test puanları arasında anlamlı bir fark var mıdır?

- Deney grubu öğrencilerinin saygılı olma eğilimleri ön test ve son test puanları arasında anlamlı bir fark var midır?

- Deney ve kontrol grubu öğrencilerinin saygılı olma eğilimleri ön test-son test puanları arasında anlamlı bir fark var midır?

- Deney grubu öğrencilerinin saygı değerine ilişkin görüşleri nelerdir?

\section{Yöntem}

Araştırmanın bu bölümünde; araştırma deseni, çalışma grubu, veri toplama araçları, uygulama süreci ve verilerin analizi konusunda açıklamalara yer verilmiştir. 


\section{Araştırmanın Deseni}

Bu araştırma, karma araştırma yaklaşımlarından gömülü desen ile yürütülmüştür. Gömülü karma desende; nitel ve nicel veriler eş zamanlı ya da sıralı olarak toplanır ve yöntemlerden birinin verileri, diğer yöntemin verilerini destekler (Rıfat, Kabakçı-Yurdakul ve Ersoy, 2014). Bu araştırmada nicel verileri desteklemek için nitel veriler kullanılmıştır.

\section{Çalışma Grubu}

Araştırma, 2017-2018 eğitim-öğretim yılında Erzurum ilinde yer alan iki farklı ilkokulun dördüncü sınıfında öğrenim gören 35 öğrenci ile yürütülmüştür. S1nıflardan biri, saygı değerine ilişkin etkinlik uygulamalarının yapıldığı (Deney Grubu [DG], n=17), diğeri ise mevcut programın uygulandığ (Kontrol grubu [KG], $\mathrm{n}=18$ ) olarak belirlenmiştir. Çalışma grubuna ait demografik bilgiler Tablo 1 'de sunulmuştur.

\begin{tabular}{cccc}
\hline \multicolumn{4}{c}{ Tablo 1: Çalışma Grubuna Dair Demografik Bilgiler } \\
\hline \multirow{2}{*}{ Gruplar } & Cinsiyet & Frekans & Yüzde (\%) \\
\hline \multirow{2}{*}{ DG } & Erkek & 12 & 34,3 \\
\cline { 2 - 4 } & K1z & 5 & 14,3 \\
\hline \multirow{2}{*}{ KG } & Erkek & 7 & 20 \\
\cline { 2 - 4 } & K1z & 11 & 31,4 \\
\hline \multirow{2}{*}{ Toplam } & & 35 & 100 \\
\hline
\end{tabular}

\section{Etik Kurul Onayı}

Bu çalışmada kullanılan veri toplama araçlarının etik açıdan uygunluğuna Atatürk Üniversitesi Sosyal ve Beşeri Bilimler Araştırmaları Etik Kurulu'ndan 21.05.2021 tarih ve 19 numaralı karar ile gerekli izin alınmıştır.

\section{Veri Toplama Araçları}

Araştırma sürecinde veri toplama araçları olarak Sarmusak tarafından geliştirilen Saygılı Olma Ĕ̆ilimi Ölçeği ve araştırmacılar tarafından oluşturulan Yarı Yapılandırılmış Görüşme Formu kullanılmıştır.

\section{Saygılı olma eğilimi ölçeği (SOEÖ)}

Etkinliklerin saygılı olma eğilimi üzerindeki etkisini belirlemek amacıyla Sarmusak (2011) tarafından geliştirilen Saygılı Olma Eğilimi Ölçeği kullanıl- 
mıştır. 14 maddeden oluşan ölçek "her zaman (4), çoğu zaman (3), çok nadir (2), hiçbir zaman (1) " olmak üzere dörtlü Likert tipinde derecelendirilmiştir. Puanlama yapılırken 1., 2., 3., 6., ve 8. maddeler tersinden toplanmaktadır. Ölçekten alınacak minimum puan 14 , maksimum puan ise 56'dır. Toplam puan deneklerin saygı eğilim puanlarını ifade eder. Puanın yüksek olması, saygı eğilimlerinin yüksek; düşük olması sayg1 eğiliminin düşük olduğunu göstermektedir. Ölçeğin Sarmusak (2011) tarafından Cronbach alfa iç tutarlık güvenirlik katsayısı ,77 olarak; bu araştırma için ise ölçeğin Cronbach alfa iç tutarlık güvenirlik katsayıs1, 81 olarak hesaplanmıştır.

\section{Yarı yapılandırılmış görüşme formu}

Araştırmanın nicel verilerini desteklemek ve saygı değerine ilişkin öğrenci görüşlerini ortaya koymak amacıyla hazırlanan Yarı Yapılandırılmış Görüşme Formu kullanılmıştır. Görüşmeler deney grubunda yer alan 17 öğrenci ile gerçekleştirilmiştir. Öğrencilere kimlik bilgilerinin gizli tutulacağı ve isimlerinin kodlanarak (Ö1, Ö2, Ö3.....Ö17) kullanılacağ1 konusunda bilgilendirme yapılmıştır.

\section{Uygulama Süreci}

Uygulama, deney ve kontrol grubunda haftada bir ders saati olmak üzere sekiz hafta sürmüştür. Deney grubunda dersler duygu ve düşüncelere sayg1 değerini kazandırmayı amaçlayan etkinlikler kullanılarak, kontrol grubunda ise mevcut programa bağlı kalınarak, sosyal bilgiler ders kitabı üzerinden yürütülmüştür. Ayrıca deney ve kontrol grubunda yer alan öğrencilere araştırma süreciyle ilgili gerekli bilgiler verildikten sonra SOEÖ ön test olarak uygulanmıştır. Ön testler uygulandıktan sonra, hazırlanan ders planlarına bağlı kalınarak deney ve kontrol gruplarında sürece başlanmıştır. Uygulama süreci deney ve kontrol gruplarında gerçekleştikten sonra SOEÖ son test olarak uygulanmış ve deney grubu öğrencileri ile görüşmeler yapılarak süreç tamamlanmıştır. Uygulama süreci Şekil 1'de sunulmuştur. 


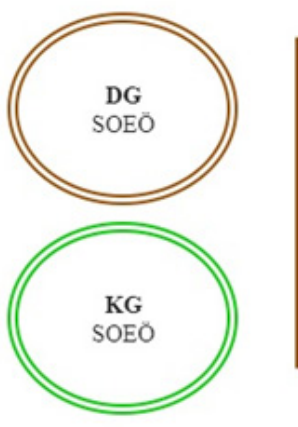

Uygulama Öncesi

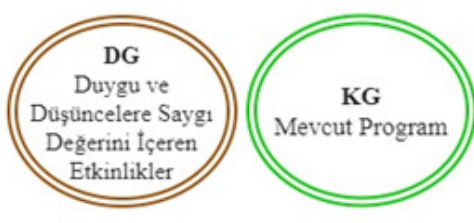

Uygulama

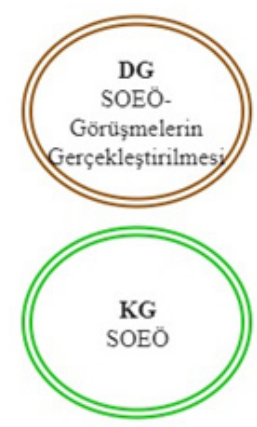

Uygulama Sonrası

Şekil 1. Uygulama Süreci

Deney ve kontrol gruplarının ders süreçleri aşağıda ayrıntılı bir şekilde anlatılmıştır.

\section{Deney grubu ders süreci}

Deney grubu uygulama sürecinin planlı yürütülebilmesi için dördüncü sınıf sosyal bilgiler dersi birey ve toplum öğrenme alanındaki kazanımlara uygun ders planları hazırlanmıştır. Süreçte kullanılacak etkinlikler, Değerler Eğitimi Merkezi (www.dem.org) adresindeki etkinliklerden yararlanılarak ve uzman görüşüne başvurularak araştırmacılar tarafından hazırlanmıştır. Etkinlikler, 2017 Sosyal Bilgiler Dersi Öğretim Programı'nın kazanımları esas alınarak ve duygu düşüncelere saygı değerini içerecek şekilde düzenlenmiştir. Uygulanan etkinliklerde; grup çalışması, beyin firtınası, video izleme, konuşma halkası, metin tamamlama, görsel okuma, ödevlendirme, tartışma, edebi metin okuma, oyun ile öğretim, soru-cevap, örnek olay, kompozisyon yazma, münazara, rol oynama teknikleri kullanılmıştır. Deney grubundaki uygulama süreci sınıf öğretmeni olan araştırmacı tarafından yürütülmüştür.

Deney grubundaki uygulama sürecinde ilgili kazanımlara ilişkin etkinlikler detaylı olarak Tablo 2'de sunulmuştur.

Tablo 2: Deney Grubu Uygulama Süreci

\begin{tabular}{lll}
\hline Hafta & Kazanım & Etkinlik \\
\hline & SB. 4.1.4. Kendisini, farklı özelliklere sahip & El Sıkışma (Tanışma Etkinliği) \\
& diğer bireylerin yerine koyar. & Mevlana ile Hacı Bektaş-1 Veli (Grup Çalış- \\
1 & $\begin{array}{l}\text { SB. 4.1.5. Diğer bireylerin farklı özellikleri- } \\
\text { ni saygı ile karşılar. }\end{array}$ & $\begin{array}{l}\text { Sen Olsaydın Ne Yapardın? (video İzleme-Ko- } \\
\text { nuşma Halkası) }\end{array}$ \\
\hline
\end{tabular}



SB. 4.1.4.Kendisini farklı özelliklere sahip
2 diğer bireylerin yerine koyar.
Tahta Kaşık (Metin Tamamlama)
SB.4.1.5. Diğer bireylerin farklı özellikleri- Görseller (Görsel Okuma) ni saygı ile karşılar.

\begin{tabular}{|c|c|c|}
\hline 3 & $\begin{array}{l}\text { SB.4.1.3. Kendisini farklı özelliklere sahip } \\
\text { diğer bireylerin yerine koyar. } \\
\text { SB.4.1.4. Diğer bireylerin farklı özellikleri- } \\
\text { ni saygı ile karşılar. } \\
\text { SB. 4.1.5. Bireysel ilgi, ihtiyaç ve yetenek- } \\
\text { lerini tanır. }\end{array}$ & $\begin{array}{l}\text { Gözle-Yaz (Ev Ödevi-Gözlem) } \\
\text { Sevgi ve Saygı (Şiir Etkinliği) } \\
\text { Farklı Özelliklerim (Video İzleme-Tartışma) }\end{array}$ \\
\hline 4 & $\begin{array}{l}\text { SB.4.1.4. Kendisini farklı özelliklere sahip } \\
\text { diğer bireylerin yerine koyar. }\end{array}$ & $\begin{array}{l}\text { Ne Yaparsınız? (Kendini Tanıma) } \\
\text { Sayg1 Oyunu (Oyun Etkinliği) } \\
\text { Resim Yapma }\end{array}$ \\
\hline 5 & $\begin{array}{l}\text { SB. 4.1.3.Kendisini, farklı özelliklere sahip } \\
\text { diğer bireylerin yerine koyar. } \\
\text { SB. 4.1.4. Diğer bireylerin farklı özellikleri- } \\
\text { ni saygı ile karşılar. } \\
\text { SB. 4.1.5. Bireysel ilgi, ihtiyaç ve yetenek- } \\
\text { lerini tanır. }\end{array}$ & $\begin{array}{l}\text { İki Gözlü Çocuk (Hikaye Tamamlama) } \\
\text { Kendimi Nasıl Görüyorum? (Etkinlik, So- } \\
\text { ru-Cevap) }\end{array}$ \\
\hline 6 & $\begin{array}{l}\text { SB. 4.1.4. Kendisini farklı özelliklere sahip } \\
\text { diğer bireylerin yerine koyar. }\end{array}$ & $\begin{array}{l}\text { Murat ile Merve } \\
\text { (Örnek Olay) } \\
\text { Kompozisyon Çalışması }\end{array}$ \\
\hline 7 & $\begin{array}{l}\text { SB. 4.1.5. Diğer bireylerin farklı özellikleri- } \\
\text { ni saygı ile karşılar. }\end{array}$ & $\begin{array}{l}\text { F1kra ile Özdeyişler (Soru- Cevap) } \\
\text { Münazara Çalışması }\end{array}$ \\
\hline 8 & $\begin{array}{l}\text { SB. 4.1.3. Kendisini farklı özelliklere sahip } \\
\text { diğer bireylerin yerine koyar. } \\
\text { SB. 4.1.4. Diğer bireylerin farklı özellikleri- } \\
\text { ni saygı ile karşılar. } \\
\text { SB. 4.1.5. Bireysel ilgi, ihtiyaç ve yetenek- } \\
\text { lerini tanır. }\end{array}$ & $\begin{array}{l}\text { Renkler ile Farklılıklar (Drama) } \\
\text { Stand Oluşturma }\end{array}$ \\
\hline
\end{tabular}

\section{Kontrol grubu ders süreci}

Kontrol grubu öğrencilerinin uygulama süreci; sınıf öğretmeni tarafindan mevcut programa bağlı kalınarak, sosyal bilgiler ders kitabı üzerinden yürütülmüştür. Bu süreçte duygu ve düşüncelere saygı değeri, 2017 sosyal bilgiler Dersi Öğretim Programı'nın kazanımlarında yer alan haliyle sosyal bilgiler ders kitabı üzerinden işlenmiştir.

\section{Verilerin Analizi}

Araştırma sorularına göre parametrik ya da nanparametrik testlerden hangisinin kullanılacağını belirlemek amacıyla normallik analizi yapılmıştır. Çalışma grubunda yer alan öğrencilerin sayıs 30 'un altında olduğu için normallik analizinde Shapiro Wilk normallik testi uygulanmıştır (Can, 2017). Normallik analizi sonucunda parametrik testlerden bağımsız gruplar $\mathrm{t}$ testinin kullanılma- 
sına karar verilmiştir. Analizler gerçekleştirilmeden önce kullanılan parametrik testlerin varsayımları incelenmiştir (Landau ve Everitt, 2004; Pituch ve Stevens, 2016; Yockey, 2011). Varyansların homojenliği varsayımı Levene testiyle incelenmiş ve bazı analizlerde karşılanmadığı görüldüğünden Welch düzeltmesi yapılmıştır (Büyüköztürk, 2011; Pallant, 2016).

Yapılan bağımsız gruplar t testi sonucunda uygulamanın ne kadar etkili olduğunu belirlemek için etki büyüklüğü hesaplanmıştır. Etki büyüklüğü değeri, 0.2 küçük, 0.5 orta, 0.8 büyük etki büyüklüğü olarak kabul edilir (Can, 2017). Araştırmada bu etki büyüklüğü dikkate alınmıştır.

Deney grubu öğrencileri ile yapılan görüşmeler sonucunda elde edilen verilerin analizinde ise içerik analizi kullanılmıştır. İçerik analizi; birbirine benzeyen verilerin belirli kavramlar ve temalar altında bir araya getirildiği ve okuyucunun anlayabileceği şekilde düzenleyerek yorumlandığı bir analizdir (Yıldırım ve Şimşek, 2016). Bu doğrultuda içerik analizi yapılırken öncelikli olarak veriler dikkatle incelenmiş ve kodlar oluşturulmuştur. Oluşturulan kodlar kontrol edilerek benzer kodlar uygun kategoriler altında toplanmıştır. Güvenirliği sağlamak amacıyla, bir sosyal bilgiler eğitimcisi ve bir sınıf eğitimcisi tarafindan bağımsız bir şekilde verileri kodlamaları ve uygun kategoriler altında toplamaları istenmiştir. Araştırmacılar ve uzmanlar arasındaki görüş birliği ve ayrılığ 1 için Miles ve Huberman'ın formülü [(Güvenirlik = görüş birliği sayıs1 / (toplam görüş birliği + görüş ayrılığı sayısı)] kullanılarak güvenirlik hesaplanmıştır. Hesaplanan bu güvenirlik katsayısının $\% 90$ olması beklenir (Baltacı, 2017). Bu araştırmada uygulamanın güvenirlik çalışmasında $\% 95$ oranında bir uzlaşma (güvenirlik) sağlanmıştır. Uzman görüşü alındıktan sonra gerekli düzeltmeler yapılarak analiz sürecine son hali verilmiştir. Öğrencilerin isimleri Ö1, Ö2, Ö3..... Ö17 şeklinde kodlanmış ve öğrencilerin ifadelerine doğrudan alıntılar yoluyla yer verilmiştir.

\section{Bulgular}

Araştırmanın bu bölümünde; veri analizinden elde edilen bulgular, araştırma soruları çerçevesinde ayrıntılı bir biçimde sunulmuştur.

\section{Kontrol Grubu Öğrencilerinin Ön test - Son Test Puanlarına İlişkin Bulgular}

Kontrol grubundaki öğrencilerin saygılı olma eğilimi ölçeğinin ön test-son test 
puanları arasında anlamlı bir farklılık olup olmadığını belirlemek amacıyla uygulanan Paired samples $t$-testi ve betimsel istatistik analiz sonuçları Tablo 3 'te sunulmuştur.

Tablo 3: Kontrol Grubu Öğrencilerinin Saygılı Olma Eğilimi Ölçeği Ön Test-Son Test Puanlarına İlişkin Betimsel İstatistik ve Paired Samples t-testi Sonuçları

\begin{tabular}{ccccccc}
\hline & $\bar{X}$ & Ss & Sd & t & p & d \\
\hline Ön Test & 48.94 & 3.57 & 17 & 2.09 & .052 & -.47 \\
Son Test & 46.78 & 5.43 & & & & \\
\hline
\end{tabular}

* p >0.05, d: Etki Büyüklüğü

Tablo 3’te, saygılı olma eğilimi ölçeğinden elde edilen verilerin tanımlayıcı istatistikleri incelendiğinde, kontrol grubunda yer alan öğrencilerin puan ortalamalarının birbirine yakın olduğu dikkat çekmektedir. Tablo 3 incelendiğinde, saygılı olma eğilimi açısından gruplar arasında istatistiksel olarak anlamlı bir farklılığın olmadığı tespit edilmiştir $\left(t_{(17)=} 2.09, p>0.05\right)$.

\section{Deney Grubu Öğrencilerinin Ön Test-Son Test Puanlarına İlişkin Bulgular}

Deney grubundaki öğrencilerin saygıll olma eğilimi ölçeği ön test - son test puanları arasında anlamlı bir farklılık olup olmadığını belirlemek amacıyla uygulanan Paired samples $t$-testi ve betimsel istatistik analiz sonuçları Tablo 4 'te sunulmuştur.

Tablo 4: Deney Grubu Öğrencilerinin Saygılı Olma Eğilimi Ölçeği Ön Test-Son Test Puanlarına İlişkin Betimsel İstatistik ve Paired Samples t-testi Sonuçları

\begin{tabular}{lcccccc}
\hline & $\bar{X}$ & Ss. & Sd & t & p & d \\
\hline Ön Test & 44.12 & 6.50 & 16 & 3.64 & $.002 *$ & 1.27 \\
Son Test & 51.12 & 4.30 & & & & \\
\hline
\end{tabular}

$* \mathrm{p}<0.05$

Tablo 4'te saygılı olma eğilimi ölçeğinden elde edilen verilerin tanımlayıcı istatistikleri incelendiğinde, deney grubu öğrencilerinin puan ortalamalarının farklılaştığ 1 tespit edilmiştir. Tablo 4 incelendiğinde, deney grubundaki öğrencilerin etkinlik temelli gerçekleştirilen uygulamalardan sonra saygı eğilim düzeylerinin anlamlı bir şekilde arttı̆̆ söylenebilir. Bu farklılık, yüksek düzeyde bir etki büyüklüğüne sahiptir $\left.\left(t_{(16)}\right)=3.64, p<0.05\right)$. 


\section{Deney ve Kontrol Grubu Öğrencilerinin Ön Test - Son Test Puanla- rına İlişkin Bulgular}

Deney ve kontrol grubundaki öğrencilerin saygılı olma eğilimi ölçeği ön test puanları arasında anlamlı bir farklılık olup olmadığını belirlemek amacıyla bağımsız gruplar $t$-testi ve betimsel istatistik sonuçları Tablo 5'te sunulmuştur.

Tablo 5: Saygılı Olma Eğilimi Ölçeği Ön Test Puanlarına ilişkin Bağımsız Gruplar t-testi Sonuçları

\begin{tabular}{llllllll}
\hline & N & $\bar{X}$ & Ss & sd & t & p & d \\
\hline KG & 18 & 48.94 & 3.57 & 24.55 & 2.70 & $.012^{*}$ & -.93 \\
DG & 17 & 44.12 & 6.50 & & & & \\
\hline
\end{tabular}

*p $<0.05$

Tablo 5'te saygılı olma eğilimi ölçeğinden elde edilen verilerin tanımlayıcı istatistikleri incelendiğinde, deney ve kontrol grubu öğrencilerinin puan ortalamaları arasında $(D G ; X=44,12 ; K G ; X=48,94)$ anlamlı bir farklılık vardır. Kontrol grubundaki öğrencilerin uygulamalar öncesinde saygılı olma eğilim düzeyleri deney grubundaki öğrencilerden anlamlı bir şekilde daha yüksektir $\left(t_{(24.55)} 2.70\right.$, $p<0.05)$. Bu farklılık, yüksek düzeyde bir etki büyüklüğüne sahiptir.

Deney ve kontrol grubundaki öğrencilerinin saygı eğilim ölçeği son test puanları arasındaki farkı incelemek amacıyla ön test puanları gruplar arasında anlamlı bir farklılık gösterdiğinden tek yönlü kovaryans analizi (ANCOVA) gerçekleştirilmiştir. Tek yönlü ANCOVA gerçekleştirilmeden önce bu testin varsayımları olan son test puanlarının her bir grup için normal dağılması varsayımı ve varyansların homojenliği varsayımları incelenmiştir. Verilerin normal dağılım gösterdiği ve varyansların homojenliği varsayımının karşılandığı görülmüştür.

Tablo 6: Saygılı olma Eğilimi Ölçeği Son Test Puanları İçin Gerçekleştirilen Tek Yönlü ANCOVA Sonuçları

\begin{tabular}{llllll}
\hline & KT & Sd & KO & F & p \\
\hline Ön Test & 35.71 & 1 & 35.71 & 1.50 & .229 \\
\hline Grup & 200.36 & 1 & 200.36 & 8.42 & $.007^{*}$ \\
\hline Hata & 761.17 & 32 & 23.79 & & \\
\hline Toplam & 961.54 & & & & \\
\hline
\end{tabular}

${ }^{*} p<0.01$.

Tablo 6'da gerçekleştirilen tek yönlü ANCOVA sonucunda öğrencilerin ön test saygılı olma eğilimi ölçeği puanları incelendiğinde, son test saygılı olma eğilimi ölçeği puanlarında gruplar arasında anlamlı bir farklılık olduğu görülmektedir $\left(F_{(1,32)}=18.42, p<0.01\right)$. Öğrencilerin ön test puanlarına göre düzetil- 
miş son test saygılı olma eğilimi ölçeği puanları deney ve kontrol grubu öğrencilerinde anlamlı bir şekilde farklılaşmaktadır. Öğrencilerin ön test puanları kontrol edildiğinde, deney grubu öğrencilerinin (Ort düz $=$ 51.61) son test puanları kontrol grubu öğrencilerinin (Ort diuz= 46.31$)$ puanlarından anlamı bir şekilde yüksektir. Öğrencilerin ön test ve son test puanlarındaki değişim grafiksel olarak Şekil 2'de görülmektedir.

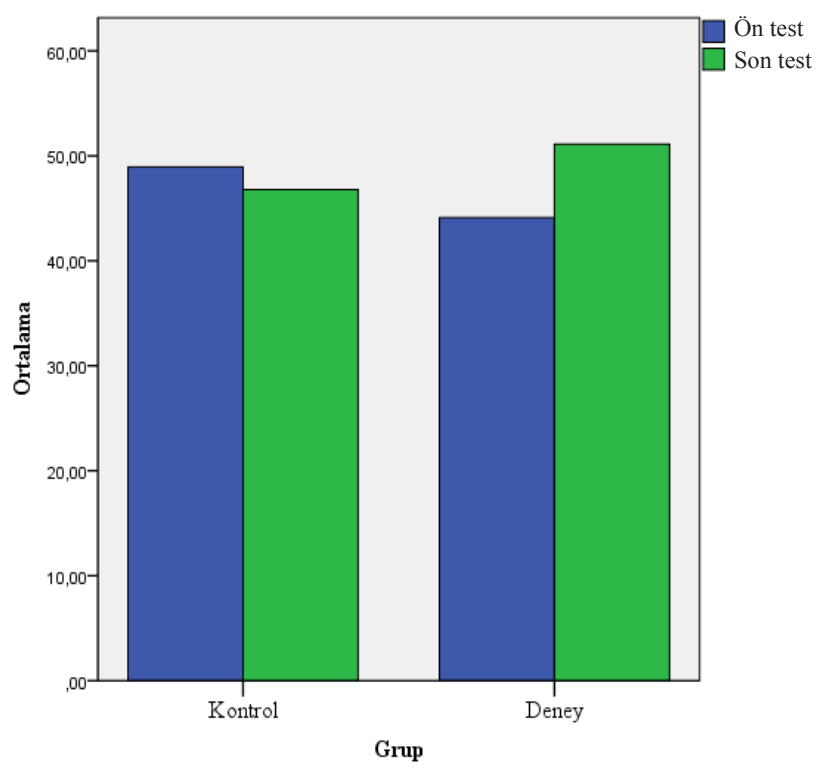

Şekil 2. Saygılı Olma Eğilimi Puanlarının Değişimi

\section{Öğrenci Görüşlerine İlişkin Bulgular}

Deney grubu öğrencilerinin saygı değerine ilişkin görüşlerini almak amacıyla öğrencilere dört soru sorulmuştur. Öğrencilerin sorulara verdikleri cevaplar incelenerek içerik analizi yapılmıştır. Görüşmelerden alınan cevaplara ilişkin bulgulara yer verilerek elde edilen bulgular tablolar halinde aşağıda sunulmuştur. Öğrencilerin görüşlerinden bazı doğrudan alıntılara yer verilmiştir.

\section{Saygılı davranmanın nedenlerine ilişkin bulgular}

Deney grubu öğrencilerine ilk olarak; "Neden insanlar birbirlerine saygıll davranmalıdır?” sorusu yöneltilmiştir. Bu soruya ilişkin öğrenci görüşleri Tablo 7'de sunulmuştur. 
Tablo 7: Saygılı Davranmanın Nedenlerine İlişkin Öğrenci Görüşleri

\begin{tabular}{|c|c|c|}
\hline Kod & Öğrenciler & Öğrenci Görüş Örnekleri \\
\hline $\begin{array}{l}\text { Çevredeki insanlarla } \\
\text { iyi geçinme isteği }\end{array}$ & $\begin{array}{l}\ddot{\mathrm{O}}_{1}, \mathrm{O}_{4}, \ddot{\mathrm{O}}_{6}, \ddot{\mathrm{O}}_{8} \\
\ddot{\mathrm{O}}_{9}, \ddot{\mathrm{O}}_{10}, \ddot{\mathrm{O}}_{12}, \ddot{\mathrm{O}}_{15}, \\
\ddot{\mathrm{O}}_{16}, \ddot{\mathrm{O}}_{17}\end{array}$ & $\begin{array}{l}\text { "Kavga ve gürültüden uzak durmak için saygılı ol- } \\
\text { malıyız. Ben diğer insanlara saygılı davranırsam on- } \\
\text { ların da bana karşı saygılı olmasını sağlarım. Birbi- } \\
\text { rimizle iyi geçinmek için saygılı olmak şarttır. (Ö8)" }\end{array}$ \\
\hline $\begin{array}{l}\text { Arkadaşlık bağlarının } \\
\text { güçlenmesi }\end{array}$ & $\begin{array}{l}\ddot{\mathrm{O}}_{1}, \ddot{\mathrm{O}}_{3}, \ddot{\mathrm{O}}_{4}, \ddot{\mathrm{O}}_{5} \\
\ddot{\mathrm{O}}_{6}, \ddot{\mathrm{O}}_{12}, \ddot{\mathrm{O}}_{13}, \mathrm{O}_{15}, \\
\mathrm{O}_{17}\end{array}$ & $\begin{array}{l}\text { "Saygının olduğu yerde kötü davranışlar uzakla- } \\
\text { şır. Arkadaşlık bağlarının daha güçlü olmasını sağlar. } \\
\text { Kalp kırılmalarının yaşanmamasının birinci şartı in- } \\
\text { sanların birbirlerine saygı olmasına bağlıdır. (Ö5)" }\end{array}$ \\
\hline $\begin{array}{l}\text { İnsanların üzülmesini } \\
\text { engelleme }\end{array}$ & $\ddot{\mathrm{O}}_{2}, \ddot{\mathrm{O}}_{7}, \ddot{\mathrm{O}}_{13}, \ddot{\mathrm{O}}_{17}$ & $\begin{array}{l}\text { "İnsanların üzülmemesi için. Aynı zamanda kendim de } \\
\text { üzülmemek için. Çünkü saygının olmadığı yerde çevrem- } \\
\text { dekiler bir gün bana da saygısızca davranacak ve ben de } \\
\text { üzüleceğim. Ayrıca insanlarla arkadaş olmak için ve on- } \\
\text { larla iyi geçinebilmek için de saygılı olmalıyım.(Ö13)" }\end{array}$ \\
\hline $\begin{array}{l}\text { Kendine saygilı } \\
\text { olunması beklentisin- } \\
\text { de olma }\end{array}$ & $\ddot{\mathrm{O}}_{8}, \ddot{\mathrm{O}}_{13}, \ddot{\mathrm{O}}_{14}$ & $\begin{array}{l}\text { "Saygının olmadığı yerde, çevremdekiler bir gün } \\
\text { bana da saygısızca davranacak ve ben de üzülece- } \\
\text { ğim. } \mathrm{Bu} \text { yüzden saygılı davranmam gerekir. (Ö13)" }\end{array}$ \\
\hline $\begin{array}{l}\text { Birlik ve beraberlik } \\
\text { oluşması }\end{array}$ & $\ddot{O}_{11}, \ddot{O}_{15}$ & $\begin{array}{l}\text { "Huzur ve kargaşanın olmadığı bir ortamda yaşamak } \\
\text { için. Kavga ve gürültüden uzak bir toplumda olmak is- } \\
\text { tediği için. Birlik ve beraberliğin sağlanması için. Ar- } \\
\text { kadaşlık ve kardeşlik duygusunun gelişmesi için. Bu } \\
\text { nedenlerden dolayı insanlara saygılı olunmalı. (Ö15)" }\end{array}$ \\
\hline $\begin{array}{l}\text { Doğru iletişim kura- } \\
\text { bilmek }\end{array}$ & $\ddot{\mathrm{O}}_{12}$ & $\begin{array}{lllllr}\text { "Herkes } & \text { birbirine } & \text { sayg1lı } & \text { olursa, o } & \text { za- } \\
\text { man doğru şekilde } & \text { iletişim } & \text { kurabiliriz. } & \text { (Ö12)" }\end{array}$ \\
\hline
\end{tabular}

Tablo 7 incelendiğinde; deney grubu öğrencilerinin saygılı davranmanın nedenlerine ilişkin verdikleri cevapların büyük bölümünü "çevredeki insanlarla iyi geçinme isteği" ve sonrasında "arkadaşlık bağlarının güçlenmesi”nin oluşturduğu görülmektedir. En az sayıda ifade edilen nedenin ise; "doğru iletişim kurabilmek" olduğu belirlenmiştir.

\section{Duygu ve düşüncelere saygı değerinin ifadesine ilişkin bulgular}

Deney grubu öğrencilerine görüşme formunda ikinci soru olarak; "Duygu ve düşüncelere saygılı olma senin için ne ifade ediyor?" sorusu yöneltilmiş ve bu soruya ilişkin öğrenci görüşleri Tablo 8'de verilmiştir. 


\begin{tabular}{|c|c|c|}
\hline Kod & Öğrenciler & Öğrenci Görüş Örnekleri \\
\hline Önemseme & $\begin{array}{l}\ddot{\mathrm{O}}_{2}, \ddot{\mathrm{O}}_{3}, \ddot{\mathrm{O}}_{7}, \\
\mathrm{O}_{8}, \mathrm{O}_{16}, \ddot{\mathrm{O}}_{17}\end{array}$ & $\begin{array}{l}\text { "İnsanların nasıl konuşmaları birbirinden farklıysa düşüncele- } \\
\text { ri de birbirinden farklı olabilir. Saygıll insan; başkasının düşün- } \\
\text { cesine de kendi düşüncesi kadar önem verir. Artık herkese say- } \\
\text { gllıyım. Önceden sadece annemin babamın ve öğretmenimin } \\
\text { düşüncesine saygllyydım ama artık herkese karşı böyleyim. (Ö2)" } \\
\text { "İnsanların duyguları ve düšünceleri bizden çok farklı da olsa onla- } \\
\text { ra saygı duymalıyız. Düşüncelerine saygı duyduğum arkadaşlarımla } \\
\text { birlikte mutlu yaşarım. Bir konuda farklı düşünsek bile ikimizin de } \\
\text { düşüncesini önemserim ve gerçekleştirmeye çalışırım. Örneğin; tek } \\
\text { bir topumuz olsa, arkadaşım yakar top oynamak istese, ben de futbol } \\
\text { oynamak istesem, onunla asla tartışmam. Fikrine saygı duyarım. Önce } \\
\text { bunlardan birisini, sonra da diğerini peş peşe oynayalım derim. (Ö3)" }\end{array}$ \\
\hline
\end{tabular}

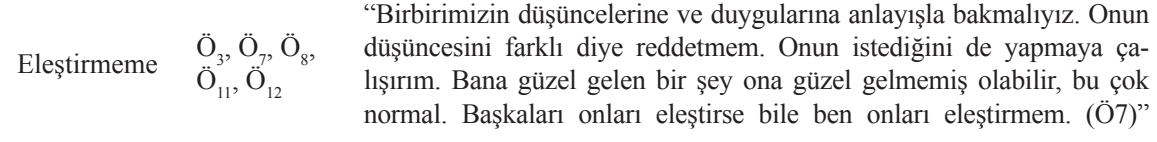

"Mesela bir arkadaşım bir şeye güldüğünde, ben ona gülmüyorsam onunla dalga geçmem. Bazı arkadaşlarımız oyun oynarken kızları oyuna almayalım diyor. Onunla bu düşüncesi yüzünden kızKizmama $\quad \ddot{\mathrm{O}}_{6}, \ddot{\mathrm{O}}_{9}, \ddot{\mathrm{O}}_{17}$ mıyorum ama anlatmaya çalışıyorum. Ona, kızlar da oyuna girsin ama hem kızların hem de erkeklerin oynayabileceği bir oyun oynayalım diyorum. Bir arkadaşım çiçekleri çok seviyor, hep onlarla oynuyor. Ben onun kadar çiçekler ile ilgilenmiyorum ama onunla dalga geçersem veya kızarsam, o benimle arkadaş olduğuna pişman olur. Hep böyle yaparsam da ilerde yalnız kalırım. (Ö17)"

\begin{tabular}{|c|c|c|}
\hline Alay Etmeme & $\ddot{\mathrm{O}}_{12}, \ddot{\mathrm{O}}_{13}$ & $\begin{array}{l}\text { "İyi ve başkalarının fikrine saygıll bir insan olmak için baş- } \\
\text { kalarının duygu ve düşünceleri ile alay etmemeliyim. (Ö13)" }\end{array}$ \\
\hline Sevme & $\ddot{O}_{14}$ & $\begin{array}{l}\text { "Benden farklı düşünen insanları da seviyorsam onla- } \\
\text { ra sayg1 duyuyorum demektir. İnsanlar farklı düşünme- } \\
\text { li, çünkü onları sayesinde yeni icatlar ortaya çıabiliyor. } \\
\text { O yüzden onlara destek bile olmalıyı ögretmenim. (Ö14)" }\end{array}$ \\
\hline
\end{tabular}

Tablo 8'de görüldüğü gibi, öğrencilerin duygu ve düşüncelere saygı değerini nasıl tanımladıklarına ilişkin verdikleri cevapların büyük bölümünü "önemseme" oluşturmaktadır. İkinci sırada ise, "eleştirilmeme" gelmektedir. En az verilen cevap ise "sevme" olarak görülmektedir. Bu yanıtı veren öğrenciler; duygu ve düşüncelere saygılı insan olmayı, karşıdaki kişiyi sevme ile ilişkilendirmiştir.

\section{Etkinliklerin saygılı olmaya etkisine ilişkin bulgular}

Deney grubu öğrencilerine üçüncü soru olarak; "Yapılan etkinliklerin saygılı olmaya etkisi hakkından neler söylersin?” sorusu yöneltilmiş ve bu soruya ilişkin öğrenci görüşleri Tablo 9'da verilmiştir. 
Tablo 9: Etkinliklerin Saygılı Olmaya Etkisine İlişkin Öğrenci Görüşleri

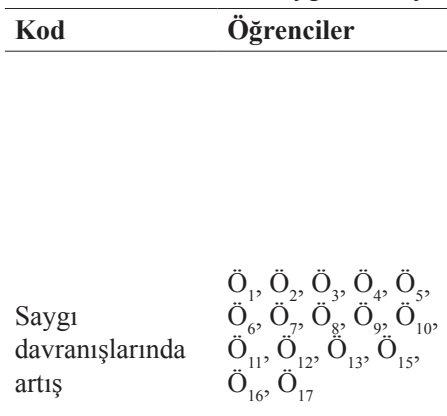

Öğrenci Görüş Örnekleri

"Daha saygılı olmaya ve bu saygıyı herkese göstermeye karar verdim. Aileme karşı daha saygılı olduğumu fark ettim. Arkadaşlarıma da daha saygıll, daha şefkatli ve iyi oldum gibi. Önceden benden farklı ve ilginç düşüncelere sahip arkadaşlarım ile dalga geçtiğim de olmuştu ama her olayda aynı düşünceleri ve duyguları yaşayamayız. Kimi sevinir, kimi sevinmez, Kimi üzülür, kimi üzülmez. Ama ben saygımı kaybetmem ve arkadaşlığımı devam ettiririm. (Ö1)" "Saygıyla ilgili düşüncelerim değişti. Daha saygılı ve dürüst davranılması gerektiğini anladım. Eskiden olsa, biri benden farklı düşünse; kızar ve ağız dalaşına girerdim. Şimdi ise karşı tarafı sinirlendirmemeye çalışıyorum. Ağzımdan çıkan laflar saygısızca olmasın diye dikkat etmeye çalışıyorum. Öncesinde saygısızca bağırdığım ve hakaret ettiğim bile oluyordu. Ama bu davranışlarımı değiştirmeye çalışıyorum. Çünkü saygının dostluğun temeli olduğunu anladım. (Ö8)"

\begin{tabular}{|c|c|c|}
\hline $\begin{array}{l}\text { Farklı fikirlere } \\
\text { destek olma }\end{array}$ & 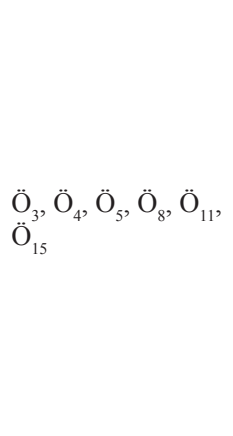 & $\begin{array}{l}\text { "Evet, daha saygıllyıım. Çünkü saygılı olmanın ne } \\
\text { kadar önemli olduğunu anladım. Bence artık saygilı } \\
\text { bir insanım. Benden farklı düşünenler de fikirlerini } \\
\text { söyleyebilsinler diye uğraşıyorum. Annem ve babamın } \\
\text { düşünceleri ve istedikleri benim isteğimden farklıysa } \\
\text { onlara karş1 düzgün konuşuyorum ve bağırmıyorum. (Ö3)" } \\
\text { "Daha saygılı biri olduğumu düşünüyorum. Sinıfta durduk } \\
\text { yere ağlayan veya benim gülmediğim esprilere gülen } \\
\text { insanlarla alay ediyordum. Daha önce, farklı fikirleri olanlara } \\
\text { da öyle. Ama şimdi, onlara karş1 saygilıyım. Hatta arkalarında } \\
\text { bile durabiliyorum diğer öğrencilere karşı ve onlara } \\
\text { fikirlerini söylemelerinde destek oluyorum. Davranışlarımda } \\
\text { değişiklikler olduğunu hissedebiliyorum. (Ö15)" }\end{array}$ \\
\hline
\end{tabular}

Uyum sağlama $\quad \ddot{\mathrm{O}}_{5}, \ddot{\mathrm{O}}_{12}, \ddot{\mathrm{O}}_{16}, \ddot{\mathrm{O}}_{17}$

"Eskisine göre daha saygılıyım. Öncesinde arkadaşlarımın düşünceleri farklıysa çok da umursamıyordum. Kızıp bağırıyordum bile. Ama şimdi daha farklı davranıyorum. Onlara uyum sağlamaya çalışıyorum. (D12)"

"Daha saygılı biri olduğumu düşünüyorum. Sinıfta durduk yere ağlayan veya benim gülmediğim esprilere gülen $\underset{\text { değişikliği }}{\text { Olumlu davranış }} \ddot{\mathrm{O}}_{2}, \ddot{\mathrm{O}}_{15}, \ddot{\mathrm{O}}_{17}$ insanlarla alay ediyordum. Daha önce farklı fikirleri olanlara da öyle. Ama şimdi onlara karşı saygılıyım. Hatta arkalarında bile durabiliyorum diğer öğrencilere karşı. Davranışlarımda değişiklikler olduğunu hissedebiliyorum. (Ö15)"

"Ben yine eskisi gibi saygılı olduğumu düşünüyorum öğretmenim. Eskiden de insanları farklı özelliklerinden Saygının $\quad \ddot{O}_{3}, \ddot{O}_{7}, \ddot{O}_{14} \quad$ dolayı aşağılamıyordum. Ama şimdi neden böyle önemini anlama davranmam gerektiğini daha iyi anladım. İnsanlar bizden farklı düşünseler de onlara da saygı duymamız gerektiğini düşünüyorum. Bu şekilde hem birbirimize daha anlayışlı oluruz hem de arkadaşlıklarımız daha güzel olur. (Ö14)"

Tablo 9'da görüldüğü gibi, öğrencilerin büyük bir çoğunluğunun etkinlikler sonrasında "saygı davranışlarında artış" olduğunu ifade ettikleri görülmektedir. 
İkinci sırada farklı "fikirlere destek olma" ardından "uyum sağlama" gibi etkileri olduğunun ifade edildiği görülmektedir.

\section{Saygı değerinin kazandırılmasında farklı etkinlik önerilerine ilişkin bulgular}

Deney grubu öğrencilerine "Saygılı insan olmanın kazandırılmaya çalışıldığı bir çalışmada hangi etkinlikleri görmek istersin?” sorusu yöneltilmiş ve bu soruya ilişkin öğrenci görüşleri Tablo 10'da verilmiştir.

Tablo 10: Öğrencilerin, Saygı Değerinin Kazandırılmasında Farklı Etkinlik Önerilerine İlişkin Görüşleri

\begin{tabular}{lll}
\hline Kod & Öğrenciler & Öğrenci Görüş Örnekleri \\
\hline Rol oynama & $\mathrm{O}_{3}, \mathrm{O}_{4}, \ddot{O}_{7}, \mathrm{O}_{13}$ & $\begin{array}{l}\text { "Sayg1 ile ilgili daha çok rol oynama ve canlandırma yaptırır- } \\
\text { dım. (Ö7)" }\end{array}$ \\
\hline Saygı köşesi & $\ddot{\mathrm{O}}_{7}, \mathrm{O}_{14}, \mathrm{O}_{16}$ & $\begin{array}{l}\text { "Sayg1 köşesi yapardım. Bütün çalışmalarımız orada sergilen- } \\
\text { sin isterdim. (Ö14)" }\end{array}$ \\
\hline
\end{tabular}

"Öğrencilerimi gruplara ayırırdım. "Birisi senden farklı düşünse ne yapardın?" diye bir canlandırma yapıp sunmalarını isterdim. Bir de şunu yapardım. Kâğıtların üzerine farklı duygular yazıp sınıfa asardım. Bir olay hakkında konuşurdum. "Böyle

Grup çalışması $\quad \ddot{\mathrm{O}}_{3}, \ddot{\mathrm{O}}_{17}$ bir olayda siz hangi duyguyu hissedersiniz?" diye sorardim. Herkesin hissettiği duygunun olduğu kâğıdın altına gitmesini isterdim. Sonra onlara; "Bakın, herkes farklı duygular hissetti. Ama hepimiz birbirimizle çok iyi anlaşıyoruz. O yüzden duygular farklı olursa, anlaşamayız diye bir şey diyemeyiz." derdim. (Ö17)"

\begin{tabular}{lll}
\hline $\begin{array}{l}\text { Kompozisyon } \\
\text { yarışması }\end{array}$ & $\mathrm{O}_{15}$ & $\begin{array}{l}\text { "Saygının önemini en iyi anlatanlara ödül verildiği bir kompo- } \\
\text { zisyon yarışması yaptırırdım okul genelinde. Birinci olanları } \\
\text { ödüllendirirdim. (Ö15)" }\end{array}$ \\
\hline Resim yapma & $\mathrm{O}_{5}$ & $\begin{array}{l}\text { "Sinıfımda ve çevremde gördüğüm saygıll davranışların resmi- } \\
\text { ni çizdirirdim öğrencilerime. (Ö5)" }\end{array}$ \\
\hline
\end{tabular}

"Saygı ile ilgili daha çok canlandırma yaptırırdım öğretme-

\begin{tabular}{lll} 
Şiir yazma & $\ddot{O}_{7}$ & $\begin{array}{l}\text { nim. Kendilerinin bir şiir oluşturmalarını isterdim. Sınıfımda } \\
\text { bir saygı köşesi yapar, saygıyla alakalı bütün etkinliklerimizi } \\
\text { oraya asardım. (Ö7)" }\end{array}$ \\
\hline Çizgi film izleme & $\ddot{O}_{1}$ & $\begin{array}{l}\text { Yine sizin yaptırdıklarınızı yaptırırdım ama belki biraz daha } \\
\text { fazla çizgi film izletirdim. (Ö1)" }\end{array}$ \\
\hline Kitap okuma & $\ddot{O}_{8}$ & $\begin{array}{l}\text { "Öğrencilerime saygının ne kadar önemli olduğunu anlatan ki- } \\
\text { taplar okuturdum. (Ö8)" }\end{array}$ \\
\hline $\begin{array}{l}\text { Saygı içerikli } \\
\text { oyunlar }\end{array}$ & $\ddot{\mathrm{O}}_{11}$ & "Saygı içerikli daha çok oyun oynatırdım. (Ö11)" \\
\hline Aynı etkinlikler & $\ddot{\mathrm{O}}_{9}, \mathrm{Ö}_{10}, \ddot{\mathrm{O}}_{12}$ & $\begin{array}{l}\text { "Farklı bir şey yapmazdım öğretmenim. Bu yapılan etkinlik- } \\
\text { lerin bana zaten bir sürü şey kattığını düşünüyorum. (Ö10)" }\end{array}$
\end{tabular}

Tablo 10'da görüldüğü gibi, saygı değerinin kazandırılmasında çeşitli etkinlik önerilerinin olduğu görülmektedir. Öğrencilerin saygı değerini kazandırmak için sundukları etkinlik önerileri arasında ilk sırayı "rol oynama" etkinliği, ardından sınıfta bir "saygı köşesi oluşturma” almıştır. 


\section{Tartışma ve Sonuç}

Bu araştırmada, dördüncü sınıf Sosyal Bilgiler Dersi Öğretim Programı'nda yer alan "duygu ve düşüncelere saygı" değerinin etkinlikler yoluyla kazandırılmasının öğrencilerin saygılı olma eğilimine etkisi incelenmiştir. Araştırma kapsamında elde edilen bulgulardan biri, etkinliklerin uygulandığı deney grubu öğrencilerinin saygılı olma eğilimi düzeyinin kontrol grubu öğrencilerinden daha yüksek olduğunu göstermiştir. Bu bulgu, alan yazında yapılan benzer çalışmaların bulgularını da destekler niteliktedir. Öztürk (2018), ilkokul dördüncü sınıf öğrencilerine yönelik hazırlanan çokkültürlü eğitim programı uygulamasının, öğrencilerin farklılıklara sayg1 düzeylerine etkisini incelemiş ve öğrencilerin farklılıklara saygı düzeylerinde anlamlı bir artış olduğunu bulmuştur. Benzer şekilde Banks (2019), çokkültürlü eğitimin öğrencilerin saygı düzeylerinde olumlu bir etki yarattığını belirtmiştir. Yine Polat ve Yıldız (2018), okulöncesi dönemi çocuklarına uyguladıkları farklılıklara saygı programının, öğrencilerdeki farklılıklara saygı düzeyine etkisini incelediği çalışmasında, deney grubu öğrencilerinde saygı düzeylerinde anlamlı bir artış olduğunu bulmuştur. İşcan (2007) ve Keskinoğlu (2008) da ilköğretim öğrencilerine uygulanan etkinlik temelli değerler eğitimi programının, öğrencilerin ahlaki olgunluk düzeylerine olumlu etkisi olduğunu belirlemişlerdir.

Araştırmada, görüşmelerden elde edilen bulgulara bakıldığında ise; öğrencilerin, insanlara karşı saygılı davranmalarının nedenlerinin; insanlarla iyi geçinebilme, birlik ve beraberlik ile arkadaşlık bağlarının güçlenmesi, aynı saygıyı diğer insanlardan da bekleme, insanların üzülmemesini sağlama ve doğru iletişim kurabilme olduğu görülmektedir. Bu bulgular, saygının tanımını ve insanlara saygılı davranma nedenlerini ortaya koyan bazı araştırmaların sonuçlarını da destekler niteliktedir. Nitekim Türk Dil Kurumu tarafından yapılan "saygı" tanımı incelendiğinde; insanların üzülmesinden ve rahatsız olmasından çekinme ve önemseme durumunun da saygı tanımı içinde geçtiği görülebilir (TDK, 2005). Ersoy (2016), dördüncü sınıf öğrencilerinin farklılıklara saygı ve hoşgörü değerlerine ilişkin yürüttüğü çalışmasında, saygılı olma davranışının, özellikle okul ortamında, insanlarla iyi geçinmek için zorunlu bir ihtiyaç olduğu sonucunu tespit etmiş̧tir. Dördüncü sınıf öğrencileri üzerinde yapılan başka çalışmalarda da farklılıklara saygı ile hoşgörü düzeyindeki artışın, öğrencilerin bulundukları ortamdaki insanlarla iyi geçinebilme düzeylerine de olumlu bir katk1 sağladığı belirtilmiştir (Aslan ve Aybek, 2018; Roth vd.,, 1996). Öğrencilerin, birbirleri ile iyi geçinerek, kavga ve kargaşa ortamı oluşabilme ihtimalini 
ortadan kaldıran saygının hâkim olduğu bir ortam sağlama hedefinde olmaya çalıştıkları söylenebilir. Yaman, vd.'nin (2009) ilköğretim öğrencilerinin etik değerlere ilişkin görüşlerini inceledikleri çalışmalarının bulgularında da benzer ifadelere rastlanmaktadır. Bu çalışmada; öğrenciler için okulda uygulanması gereken en önemli değerlerden birinin "kimseye rahatsızlık vermemek" olduğu görülmektedir. Bununla beraber öğrencilerin birbirleri ile iyi geçinebilme çabası içinde olmaları; aralarındaki bağlılık, birlik ve beraberlik ile arkadaşlık ilişkilerine de olumlu yönde etki edebilir. Bu şekilde olumlu ilişkiler kurulabilmesini sağlayan önemli değerlerden biri olan saygı ise (Kıral, 2018), çocukların sağlıklı arkadaşlık ilişkileri kurabilmeleri için gereklidir (Felmlee ve Muraco, 2009). Öğrenciler; birbirlerinin farklılıklarına, duygularına ve düşüncelerine karş1 sayg1 göstererek, farklılıklardan dolayı oluşabilecek ön yarg1 ve hoşgörüsüzlük problemleri ile karşılaşıp arkadaşlarının üzülmelerinin önüne geçebileceklerini düşünebilirler. Bununla birlikte öğrenciler, saygıll olma bilinci geliştirerek kendilerinin de farklılıklarından dolayı benzer problemler yaşayabilme olasılıklarının önüne geçmeye çalışıyor olabilirler. Çünkü saygı gösterebilmek, aynı saygıyı görebilmenin temel şartı konumundadır (Kıral, 2018). Bu nedenle; öğrenciler, kendilerinin karşılaşmak istedikleri saygı kadar, karşılarındaki kişilere de sayg1 gösterebilmelidir (Littauer ve Littauer, 2005).

Öğrencilerin duygu ve düşüncelerine sayg1 değerini; insanları önemseme, eleştirmeme, kızmama, alay etmeme ve sevme durumları şeklinde ifade ettikleri görülmektedir. İnsanların ve görüşlerinin önemsenmesinin, insanların üzülmesinin önüne geçilmeye çalışılmasının saygı kavramına ait özellikler olduğunu ortaya koyan çalışmalar mevcuttur (Akkoyun, 2016; Arıcı ve Maden, 2018). Ancak araştırma ile ilgili alanyazın taraması yapıldığında, duygu ve düşüncelere sayg değerinin öğrenciler açısından neler ifade ettiğgine dair çalışmalara sinırlıdır (Aslan, 2019). Bununla birlikte bu çalışmada, duygu ve düşüncelere saygı değerinin ifade ettiği kavramların, saygı değeri ile ilişkilendirilebilir olduğu söylenebilir. Sayg1 kavramında olduğu gibi, duygu ve düşüncelere sayg1 kavramının da temelinde, farklılıkları önemseme vardır (Arıcı ve Maden, 2018). Öğrenciler, olay ve durumlara karşı kendilerinden farklı olarak ortaya çıkan duygu ve düşünce durumlarını kızmadan, alay etmeden karşılayarak duygu ve düşüncelere saygılı bir birey gibi hareket ettiklerini düşünebilirler. Aynı zamanda öğrenciler, farklı düşüncelerin aksi veya farklı bakış açılarında yorumlar yapmadıklarında, yani olumsuz eleştiride bulunmadıkları takdirde farklı düşüncelere saygılı olduklarını düşünmektedirler. Ancak öğrencilerin farklı düşünceleri kritik edebilmeleri ve yapılan eleştiriden ders çıkarabilmeleri, onlar 
için önemli bir gerekliliktir. Çünkü doğru yapılan eleştiri ile farklı düşüncelerin alışverişi gerçekleşip yeni öğrenmeler sağlanabilir (İnam, 1994).

Etkinliklerin saygılı olmaya etkisine yönelik olarak öğrenciler, etkinlikler sayesinde saygılı davranmada artış yaşadıklarını, farklı fikirlere karşı desteklerinin daha çok arttığını, çevresindeki insanlar ile uyum sağlayabilme davranışlarında iyileşme meydana geldiğini, kendilerinde olumlu davranış değişikliği oluştuğunu fark ettiklerini ve saygının önemli olduğunu daha iyi anladıklarını ifade etmişlerdir. Bu bulgular Aktepe'nin (2010), yardımseverlik değerinin etkinlik temelli öğretiminin öğrenci tutumuna etkisini incelediği çalışmasında, etkinliklerin öğrenci tutumlarını olumlu yönde etkilediği sonucuyla benzerlik göstermektedir. Üner (2011), farkl1lıklara saygı eğitim programının uygulanması ile ilgili yaptı̆̆ çalışmasında; farklılıklara saygı programının, öğrencilerin bütün gelişim alanlarına olumlu katkı sağladığını bulmuştur. Aynı şekilde Rosenzweig (1999), çokkültürlü eğitim programı uygulamasının öğrencilerin sosyal biliş düzeyine etkisini incelediği çalışmasında, çok kültürlü eğitim programının, öğrencilerin ahlaki ve sosyal alanlardaki becerilerini geliştirdiğini tespit etmiştir. Topcubaşı (2015), farklılıklara saygı eğitim programının, farklılıklara sayg1 düzeyine etkisini incelediği çalışmasında, sayg1 eğitimi ile öğrencilerin empatik düşünme becerileri ve sosyal yeterliliklerinde artış sağlandığı sonucuna ulaşmıştır. Aynı zamanda; yapılan etkinlikler ile saygının insanlar ve toplumlar için ne kadar önemli olduğunun anlaşılabilmiş olması sonucu göz önüne alındığında, öğrencilerin kendilerine ait bir "saygı bilinci" kavramı oluşturmaya başladıkları veya sahip oldukları bu bilinci daha da geliştirebildikleri söylenebilir. Başka bir deyişle öğrencilerin farklı etkinlikler ile karşılaştırılması, onların saygı değerine karşı farkındalık ve duyarlılık kazanmalarını sağlayabilir.

Öğrencilerden, farklı etkinlik önerilerinin neler olduğu konusundaki görüşlerine bakıldığında; rol oynama ile grup çalışmalarına ağırlık verilmesi, okulda bir saygı köşesinin olması gerektiği, saygı temalı kompozisyon yarışması ile resim yapma, şiir yazma, çizgi film izleme, saygı içerikli oyunlar oynama etkinliklerine ağırlık verilebileceği, saygı değeri temalı kitaplar okutulabileceği sonuçlarına varılmıştır. Ulaşılan bulgular; duygu ve düşüncelere saygı değerini kazandırmaya yönelik yapılan etkinliklerin öğrencilerde eğitsel bir doyum sağladığını gösterebilir. Konu ile ilgili yapılan benzer çalışmalar ise, öğrencilerin çoğunluğunun görüşünü destekler niteliktedir. Halstead (1996), okullarda değerler eğitimini incelediği araştırmasında; rol oynama ve dramatizasyon, grup çalışmaları, sınıf içi etkinlikler ve eğitici oyunların kullanılabileceğini benzer şekilde Berkant, Efen- 
dioğlu ve Sürmeli de (2014), rol oynama ve drama çalışmalarının öğrencilere değer kazandırmada etkili olabilecek teknikler olabileceği üzerinde durmuşlardır. Dolayısıyla etkinlik temelli bir değerler eğitimi programında, rol oynama, grup çalışmaları ile oyunlar gibi öğrenciyi süreçte aktif kılan çalışmaların ağırlıklı bir şekilde yer almasının gerekli olduğu söylenebilir. Başka bir çalışmada ise (Fidan, 2009), değer temalı filmlerin izletilmesinin, değer kazandırma sürecinde etkili olduğu sonucuna ulaşılmıştır Okullarda oluşturulabilecek sayg köşesi de değer kazandırmanın görsel boyutunu oluşturan etkinliklerden birisidir. Alanyazın taramasında saygı köşesi oluşturma ile ilgili çalışmaya rastlanmazken, saygı köşesi ile paralel amaçları taşıyan "iyilik köşesi” etkinliğinin gerçekleştirildiği çalışmalar bulunmaktadır (Arabacı ve Akgül, 2013). İyilik köşesi oluşturma etkinliğinin öğrencilerin "iyilik yapma" değeri üzerinde etkili olduğu sonucuna ulaşılmıştır. Bu bulgulardan hareketle okullarda hazırlanan değer köşelerinin değer kazandırma sürecinde faydalı olabilecek çalışmalar olduğu söylenebilir. Bununla birlikte değer kazandırma sürecinde görsel içerikli çalışmalara ek olarak edebi metinlere ve yazma çalışmalarına da yer verilebilir. Benzer çalışmalarda elde edilen bulgular da bu görüşü doğrular niteliktedir. Şiir ve kompozisyon çalışmaları (Yaman vd., 2009), edebi metinler (Bohlin, 2005) ve masallardan (Çayır, 2003; Uçar, 2007) yararlanılmasının değer ve karakter eğitimi sürecinde etkili olduğuna vurgu yapilmaktadır.

Sonuç olarak, yapılan bu araştırma dördüncü sınıf Sosyal bilgiler Dersi Öğretim Programı'nda yer alan "duygu ve düşüncelere saygı” değerinin etkinlik temelli öğretiminin öğrencilerin saygıll olma eğilimini olumlu yönde etkilediğini ortaya koymuştur. Bu bulgular ışığında, değer kazandırma sürecinde öğrenciyi aktif hale getirecek ve yaparak yaşayarak öğrenmesini sağlayacak etkinlikler sunulmasının, öğrencilerin değerleri içselleştirebilmelerinde oldukça önemli bir araç olduğu, değerlerin bireysel ve toplumsal açıdan önemini daha iyi algıladıkları, öğrencilerin görsel becerilere dayalı etkinliklerle daha çok karşılaşmak istedikleri, etkinlik temelli öğretimin öğrencileri değer kazanma sürecinde daha istekli, aktif ve grup çalışmalarına katılmaya istekli hale getirdiği sonuçlarına ulaşılabilir. Araştırmanın ulaştığı sonuçlar doğrultusunda şu önerilerde bulunulabilir:

- Programda yer alan değerlerin kazandırılmasında etkinlik temelli öğretim sürecine yer verilebilir.

- Değer kazandırma sürecinde; farklı yöntem ve tekniklerin kullanıldığı, içeriği zenginleştirilmiş etkinliklere yer verilebilir. 


\section{Kaynakça}

Akın, M. F. (2007). Özdeşlik konusunun öğretiminde yapılandırmacı öğrenme yaklaşımının öğrenme ürünlerine etkileri (Yüksek lisans tezi). Dicle Üniversitesi Fen Bilimleri Enstitüsü, Diyarbakır.

Aktepe, V. (2010). Ilkögretim 4. sinff sosyal bilgiler dersinde "yardımseverlik" değerinin etkinlik temelli öğretimi ve ögrencilerin tutumlarına etkisi (Doktora tezi). Gazi Üniversitesi Eğitim Bilimleri Enstitüsü, Ankara.

Akkoyun, F. (2016). Saygı kavramına transaksiyonel analiz (TA) açısından bakış. Türk Psikolojik Danışma ve Rehberlik Dergisi, 1(4).

Albayrak, F. (2015). Illkokul sosyal bilgiler kazandırllan değerlerle ilgili sınıf ögretmenlerinin görüşleri (Yüksek lisans tezi). Atatürk Üniversitesi Eğitim Bilimleri Enstitüsü, Erzurum.

Arabacı, İ. B. ve Akgül, T. (2013). Elazı̆̆ ilinde uygulanan etkinlik temelli değer öğretimi uygulamalarının değerlendirilmesi. Değerler Eğitimi Dergisi, 11(25), 7-31.

Arıc1, İ. ve Maden, K. (2018). İlköğretim Din Kültürü ve Ahlak Bilgisi öğretim programında saygı değeri. Journal of Graduate School of Social Sciences, 22(1).

Aslan, S. (2019). İlkokul 4. sınıf öğrencilerinin duygu ve düşüncelere saygı ile hoşgörü tutumları ve görüşlerinin incelenmesi. e-Uluslararası Eğitim Araştırmaları Dergisi, 10(2), 80-95.

Aslan, S. ve Aybek, B. (2018). İlkokul 4. sınıf öğrencilerinin çokkültürlü eğitime dayalı olarak uygulanan etkinlikler ile ilgili görüşlerinin incelenmesi. Kuramsal Ĕ̌itim Bilim Dergisi, 11(1), 58-82.

Aydın, M. Z. (2010). Okulda çalışan herkesin görevi olarak değerler eğitimi. Değerler Ĕgitimi Buluşması, 22.

Balc1, F. A. ve Yelken, T. Y. (2013). İlköğretim sosyal bilgiler programında yer alan değerler ve değer eğitimi uygulamaları konusunda öğretmen görüşleri. Ahi Evran Üniversitesi Kırşehir Ĕ̈itim Fakültesi Dergisi, 14(1), 195-213.

Baltac1, A. (2017). Nitel veri analizinde Miles-Huberman modeli. Ahi Evran Üniversitesi Sosyal Bilimler Enstitüsü Dergisi, 3(1), 1-15.

Banks, J. A. (2019). An introduction to multicultural education. New York Pearson.

Barcın, F. (2018). İlkokul 4. sınıf değerler eğitiminde yaratıcı drama yönteminin etkisi (Yüksek lisans tezi). Gaziantep Üniversitesi Eğitimi Bilimleri Enstitüsü, Gaziantep.

Berkant, H. G., Efendioğlu, A. ve Sürmeli, Z. (2014). Değerler eğitimine yönelik 
öğretmen görüşlerinin incelenmesi. Electronic Turkish Studies, 9(5). http:// dx.doi.org/10.782.7/TurkishStudies.6732

Bohlin, K. E. (2005). Teaching Character Education Thorough Literature. London. Büyüköztürk, Ş. (2011). Sosyal bilimler için veri analizi el kitabı. Pegem Akademi. Can, A. (2017). SPPS ile bilimsel araştırma sürecinde nicel veri analizi (5. Bask1). Pegem Akademi.

Çatlak, İ. (2017). Sosyal bilgiler öğretmen adaylarına empati becerisi ve farklılıklara saygılı olma değerinin kazandırılmasında storyline yönteminin etkisi (Yüksek lisans tezi). Abant İzzet Baysal Üniversitesi Eğitim Bilimleri Enstitüsü, Bolu.

Çayır, K. (2003). İnsan hakları ve demokrasi kültürünün geliştirilmesi: Ders kitaplarının yazımı. M. T. Bağlı ve Y. Esen (Ed.), Ders kitaplarında insan haklart: Insan haklarına duyarlı ders kitapları için. (ss. 21-45). Tarih Vakfi Yayınları.

DEM, Değerler Eğitimi Merkezi. (2017). https://degerler.org/kademe/saygi/ ilkokul-3-4 adresinden 05.09.2017 tarihinde alınd1.

Demir, B. (2008). Adalet ve saygl içerikli karakter ĕgitimi programının 7. sınıf ögrencilerinin ahlaki olgunluk düzeylerine etkisi (Yüksek lisans tezi). Yeditepe Üniversitesi Sosyal Bilimler Enstitüsü, İstanbul.

Ekmişoğlu, M. (2007). Erken çocukluk döneminde farklılıklara saygı kavramı hakkında ögrretmen görüşlerinin incelenmesi ve farklılıklara saygı ölçeğinin geçerlik ve güvenirlik çalışması (Yüksek lisans tezi). Onsekiz Mart Üniversitesi Sosyal Bilimler Enstitüsü, Çanakkale.

Eren, S. (2015). Öyküleştirme yöntemine dayalı ĕgitimin beş yaş çocuklarında farklılıklara saygı kazanımına etkisinin incelenmesi (Yüksek lisans tezi). Hacettepe Üniversitesi Eğitim Bilimleri Enstitüsü, Ankara.

Ersoy, A. (2016). Dördüncü sınıf öğrencilerinin hoşgörü algısı ve deneyimleri: Bir fenomenolojik araştırma. Mersin Üniversitesi Eğitim Fakültesi Dergisi, 12(1). https://doi.org/10.17860/efd.31740

Felmlee, D. ve Muraco, A. (2009). Gender and friendship norms among older adults. Research on Aging, 31(3), 318-344.

Fidan, N. K. (2009). Öğretmen adaylarının değer öğretimine ilişkin görüşleri. Kuramsal Ĕ̈itim Bilim Dergisi, 2(2), 1-18.

Gülmüş, R. (2015). İlkokul 4. sınıf sosyal bilgiler dersi tarih konularında değer ögretimine ilişkin sınıf ögretmeni görüşleri (Yüksek lisans tezi). Mehmet Akif Ersoy Üniversitesi Eğitim Bilimleri Enstitüsü, Burdur.

Gümüş, O. (2016). İlkokul 4. Sinıf sosyal bilgiler dersinde Türk büyüklerine saygl, aile birliğine önem verme ve vatanseverlik değerinin karma yaklaşıma dayalı etkinliklerle ögretimi (Yüksek lisans tezi). Gazi Üniversitesi Eğitim 
Bilimleri Enstitüsü, Ankara.

Güven, S. (2012). Sınıf Öğretmeni adaylarının farklılıklara saygı düzeyleri ile özerklik düzeyleri arasındaki ilişkinin incelenmesi (Yüksek lisans tezi). Ondokuz Mayıs Üniversitesi Eğitim Bilimleri Enstitüsü, Samsun.

Halstead, J. M. (1996). Values and values education in schools. Values in education and education in values, 3-14.

İnam, A. (1994). Eğitimi eleştirmek. Bilim ve Teknik, 316, 64-67.

İscan, C. D. (2007). Illköğretim düzeyinde değerler ĕgitimi programının etkililiği. (Doktora tezi). Gazi Üniversitesi Sosyal Bilimler Enstitüsü, Ankara.

Kacar, M. (2018). Sınıf ögretmeni adaylarında çokkültürlü kişiliğin farklılıklara saygl üzerindeki etkisinin incelenmesi (Yüksek lisans tezi). Dumlupınar Üniversitesi Eğitim Bilimleri Enstitüsü, Kütahya.

Kalem, S. ve Fer, S. (2003). Aktif öğrenme modeliyle oluşturulan öğrenme ortamının öğrenme, öğretme ve iletişim sürecine etkisi. Educational Sciences: Theory \& Practice, 3(2). https://doi.org/10.19126/suje.346975

Kavun, M. (2018). Çocuklara değer aktarımında Türk sinemasının rolü: Kemal Sunal filmleri örneği (Yüksek lisans tezi). Ondokuz Mayıs Üniversitesi Eğitim bilimleri Enstitüsü, Samsun.

Keskinoğlu, M. Ş. (2008). İlköğretim beşinci sınıf ögrencilerine uygulanan mesnevi temelli değerler eğitimi programının ahlaki olgunluğa ve saldırganlık eğilimine etkisi (Yüksek lisans tezi). Yeditepe Üniversitesi, Sosyal Bilimler Enstitüsü.

Kıral, E. (2018). Kayıp giden bir değer: saygı. Çağdaş Yönetim Bilimleri Dergisi, 5(1), 4-9.

Kösterelioğlu, I., Bayar, A. ve Kösterelioğlu, M. (2014). Öğretmen eğitiminde etkinlik temelli öğrenme süreci: Bir durum araştırması. Electronic Turkish Studies, 9(2). http://dx.doi.org/10.7827/TurkishStudies.6406

Landau, S. ve Everitt, B. S. (2004). A handbook of statistical analyses using SPSS. Boca Raton: Chapman \& Hall ; CRC.

Littauer, F. ve Littauer, M (2005). Kişilik bulmacası. H. B. Çelik (Çev. Ed.). Sistem Yayıncilik.

Loomans, D. ve Loomans, J. (2005). Çocuklara öz sayglyı ve değerleri ögretmenin 100 yolu. T. Göbekçin (Çev. Ed.). Ege-Meta Yayınları.

MEB. (2017). Sosyal bilgiler dersi ögretim programı (İlkokul ve Ortaokul 4, 5, 6, 7 ve 8. Sinıflar). Ankara: Devlet Kitapları Basımevi.

Özden, Y. (2005). Eğitimde yeni değerler; Eğitimde dönüşüm. Pegem A Yayıncılık. Özensel, E. (2003). Sosyolojik bir olgu olarak değer. Değerler Ĕ̆itimi Dergisi, 1(3), 
217-240.

Özkan, Z. S. (2017). Hayat bilgisi ders kitaplarındaki metin ve görsellerin değerler açısından incelenmesi (Yüksek lisans tezi). Ordu Üniversitesi Sosyal Bilimler Enstitüsü, Ordu.

Öztürk, F. (2018). Çokkültürlü eğitim çerçevesinde hazırlanan etkinliklerle farklılıklara saygı değeri ve araştırma becerisi geliştirmeye yönelik bir eylem araştırması (Doktora tezi). Çukurova Üniversitesi Sosyal Bilimler Enstitüsü, Adana.

Pallant, J. (2016). SPSS kullanma kılavuzu, SPSS ile adım adım veri analizi. Ankara: Anı Yayıncılık.

Polat, Ö. ve Yıldız, T. Ö. (2018). 5-6 yaş grubu için geliştirilen aile katılımlı farklılıklara saygı programının çocukların farklılıklara saygı düzeyine etkisinin incelenmesi. Eğitimde Kuram ve Uygulama, 14(4), 389-403. https://doi. org/10.17244/eku.466812

Pituch, K. A. ve Stevens, J. (2016). Applied multivariate statistics for the social sciences: analyses with SAS and IBM's SPSS. New York: Routledge.

Rıfat, M., Kabakçı-Yurdakul, I. ve Ersoy, A. (2014). Bir eğitim teknolojisi araştırmasına dayalı olarak karma yöntem araştırması deneyimi. Eğitimde Nitel Araştırmalar Dergisi, 2(1), 65-86. https://doi.org/10.14689/issn.21482624.1.2s3m

Rosenzweig, J. E. (1999). I have a new friend in me: The effect of a multicultural/ anti-bias curriculum on the development of social cognition in preschoolers (Doctoral thesis). University of Arizona, USA.

Roth, N. L., Hunt, T., Stavropoulos, M. ve Babik, K. (1996). Can’t we all just get along: Cultural variables in codes of ethics. Public Relations Review, 22(2), 151-161.

Sarmusak, D. (2011). İlkögretim öğrencilerinin empatik ĕgilimleri ve alglladıklarl ögretmen tutumlarının öğrencilerin ahlaki değer yargılarına etkisi. (Yüksek lisans tezi). Gazi Üniversitesi Eğitim Bilimleri Enstitüsü, Ankara.

TDK (2005). Türk Dil Kurumu Sözlüğ̈̈̈. Ankara: Türk Dil Kurumu Yayınları.

Topcubaşı, T. (2015). Farklılıklara saygl ĕgitim programının öğrencilerin farklılıklara saygı düzeyine etkisi (Yüksek lisans tezi). Kocaeli Üniversitesi Sosyal Bilimler Enstitüsü, Kocaeli.

Uçar, G. (2007). Ayla Çınaroğlu'nun “Keçi Masalı” adlı eserinde toplumsal bilinç eğitimi. Selçuk Üniversitesi Sosyal Bilimler Enstitüsü Dergisi, 18, 455-461.

Üner, E. (2011). Okul öncesi eğitim programındaki 36-72 aylık çocuklara farklılıklara saygı ĕgitimi kazandırmanın öğretmen görüşleri doğrultusunda değerlendirilmesi (Yüksek lisans tezi). Erciyes Üniversitesi Eğitim Bilimleri 
Enstitüsü, Kayseri.

Yaman, E., Mermer, E. Ç. ve Mutlugil, S. (2009). İlköğretim okulu öğrencilerinin etik davranışlara ilişkin görüşleri: Nitel bir araştırma. Değerler Ĕ̆itimi Dergisi, 7(17), 93-108.

Yıldırım, A. ve Şimşek, H. (2016). Sosyal bilimlerde nitel araştırma yöntemleri (10. Baskı). Ankara: Ayrıntı Basım, Yayın ve Matbaacılık.

Yıldırımçakar, A. (2018). Illkokul ve ortaokul ögretmenlerinin informal ilişki düzeyleri ile farklılıklara saygı düzeyleri arasındaki ilişki (Yüksek lisans tezi). Yüzüncü Yıl Üniversitesi Eğitim Bilimleri Enstitüsü, Van.

Yockey, R. D. (2011). SPSS demystified: a step-by-step guide to successful data analysis. Boston: Prentice Hall. 
Extended Abstract

\section{The Impact of Activity-Based Teaching of the Value of Respecting the Feelings and Opinions of Others on the Students' Inclination to Respect}

Yasemin ALTUNSOY, Ph. D. Student

Trabzon University, Institute of Gradute Studies, Trabzon / Turkey

y.kinalioglu_61@hotmail.com

https://orcid.org/0000-0001-6969-0853

Zeynep BAŞGI NAMLI, Corresponding Author, Assistant Professor Atatürk University, Kazım Karabekir Faculty of Education, Erzurum / Turkey

zbasci@atauni.edu.tr

https://orcid.org/0000-0003-2865-5976

Article Type: Research Article

https://doi.org/10.34234/ded.899968

Received Date: 06.07 .2021

Accepted Date: 23.10 .2021

Published Date: 25.12.2021

\section{Introduction}

The most integral parts that make up the socio-cultural background of a society are formed by the individuals who live within that society (Özensel, 2003). In this context, schools act as institutions that aim to raise individuals with appropriate knowledge, skills, and values, to build up such background. Nowadays, schools also seek to provide students with the necessary skills to conti- 
nue their lives as well-trained and self-actualized individuals, to raise them as "good people", and enabling them to achieve academic success. Undoubtedly, values play an important role in such an aim of raising good people. Conducting an effective values education, especially at primary schools, helps students to build healthy personalities that can shape better future for them (Albayrak, 2015). Being among such values, "respect" is a critical one that students must acquire. Moreover, respect is a fundamental value that includes a great variety of meanings, intuitions, in such a way that provide the foundation (Loomans \& Loomans, 2005). In fact, when students become aware of the value of being respectful to different opinions and why they should do so, this consciousness may positively affect their process of internalizing different values along with respect and enhance the development of their personalities as a whole. One of the sub-concepts of the value of respect is "respect for feelings and opinions of others" (MoNE, Social Studies Curriculum, 2017)

The process of acquiring students with values whether explicitly or implicitly through the curriculum could be based on some approaches which can be traditional or student-centred ones. However, emerging new approaches reveal the necessity of a new arrangement of practices intertwined with activities so that students are placed at the centre in the process of instilling values in them, as is the case in every acquisition activity (Özden, 2005). Relying on the active participation of students, the activity-based teaching process in which the students are at the centre is a constructivist learning and teaching process that aims to enable students to access information in an active manner through various activities, and to ensure that students become motivated and educationally satisfied at the end of the activities (Kalem \& Fer, 2003). Drawing on a variety of activities that will put the student at the centre during an activity-based value acquisition process can be influential in that each student can create their own value judgments and value systems as a separate individual. In addition, when encountered various activities, it is believed that students will be likely to be more active and motivated in the process of gaining values, and to experience an enjoyable learning process (Akın, 2007).

Due to the lack of relevant studies conducted on how to instil the value of respect for feelings and opinions of others via educational activities, and as the studies in the literature have proved that teaching via educational activities have a positive effect on the acquisition of values and attitudes. This study aims to examine the use of educational activities aiming at making students gain the 
value of "respect for feelings and opinions," which set in the Social Studies Curriculum of Grade 4, and their impact on students' inclination to become respectful individuals. Based on this general objective, the study sought to answers the following questions:

- Is there a statistical significance between the pre-test and post-test scores of the control group students' tendency to be respectful?

- Is there a statistical significance between the pre-test and post-test scores of the experimental group students' tendency to be respectful?

- Is there a statistical significance between the pre-test and post-test scores of the experimental and control group students' tendencies to be respectful?

- What are the opinions of the experimental group students about the value of respect?

\section{Method}

We employed an embedded research approach in order to determine the impact of activities prepared to make students gain the value of respect for feelings and opinions of others on their tendency to respect by using the activity-based teaching technique.

\section{Sample Group, Data Gollection and Data Analysis}

This study was conducted with 35 students studying in Grade 4 at two different primary schools in Erzurum, Turkey, in the 2017/18 academic year. Data was collected via the Tendency to Be Respectful Scale developed by Sarmusak and the Semi-Structured Interview Form created by the researchers. Independent groups $t$-test was used to analyse the data obtained from the scale, and content analysis was used to analyse the interviews with the students.

\section{Results, Discussion and Gonclusion}

This study investigated the effect of instilling the value of "respect for feelings and opinions" on students through the activities included in Social Studies curriculum for Grade 4 via on the students' tendency to be respectful. The data analyses indicates no statistical significance between pre-test and post-test scores of the students in the control group related to the tendency to be respectful, while a statistical significance was founded between scores of the students in the experimental group. Consequently, it appears that the level of tendency of 
the students in the experimental group related to showing respect increased significantly after the activity-based practices. Such results also support the findings of similar studies found in the relevant literature (İşcan, 2007; Keskinoğlu, 2008; Öztürk, 2018; Polat \& Y1ldız, 2018; Banks, 2019).

The findings from the interviews show that the reasons why the students behave respectfully towards people stem from the motives of getting along well with people, strengthening the bonds of friendship with unity and solidarity, expecting the same respect from others, making sure that people do not get upset, and developing the right kind of communication. In another study conducted with Grade 4 students on the values of respect and tolerance for differences, Ersoy (2016) emphasized that respectful behaviour is a compulsory need to get along with people, especially in the school environment. Furthermore, some other studies conducted with Grade 4 students reported that the increased level of respect for differences and tolerance also contribute positively to the likelihood of students to get along with people in their environment (Aslan \& Aybek, 2018; Roth, Hunt, Stavropoulos \& Babik, 1996).

This study revealed that the students attribute meanings to the value of respect as; caring for feelings and opinions of people, not criticizing them, not getting angry with them, not mocking them, but rather loving them. Several studies in the literature support our findings since they have reported that caring for people and their opinions, and trying to prevent people from getting upset are the among the characteristics of the concept of respect (Akkoyun, 2016; Ar1c1 \& Maden, 2018).

Regarding the impact of the activities related to being respectful, the students stated that the activities helped them improve their tendency to behave respectfully, their sense of support for different ideas, and their behaviour in adapting to the people around them, and that they came to realize that they experienced a positive behavioural change, and understood better the importance of respect. Such findings are similar to what Aktepe (2010) reported in a study that investigated teaching benevolence as a value via activity-based teaching approach in terms of its impact on student attitude, concluding that activities positively affect student attitudes. In a study examining the effect of a multicultural education program on the social cognition levels of the students, Rosenzweig (1999) found that the multicultural education program improved the students' moral and social skills.

When asked about their opinions on different activity suggestions, the stu- 
dents stated that role playing and group work should be used more, that there should be a respect corner in the school, that an essay contest on the theme of respect could be organized, that certain activities such as painting, writing poetry, watching cartoons, and playing games in relation to showing respect could be integrated into the teaching processes, and that book-reading activities could be carried out with the theme of showing respect. Halstead (1996) maintained that role playing and dramatization, group work, in-class activities and educational games can be used to teach values at school. Similarly, Berkant, Efendioğlu, and Sürmeli (2014) emphasized that role-playing and drama studies may turn out as effective techniques to instil in students the necessary values (Fidan, 2009), and concluded that watching value-themed films proved effective in the process of values aquisition. However, some other studies, have emphasized that the use of poetry and essay-writing activities (Yaman, Mermer, \& Mutlugil, 2009), literary texts (Bohlin, 2005) and fairy tales (Çayır, 2003; Uçar, 2007) is an effective way of teaching values and character education.

In conclusion, this study has revealed that the activity-based teaching of the value of "respect for feelings and opinions of others" included in the Social Studies Curriculum for Grade 4 positively affects the students' tendency to be respectful. In the light of such findings, it could be concluded that presenting activities during value acquisition process, that activate the students and enable them to learn by doing is of great importance. On one hand, students can internalize values and perceive their importance better on both individual and social levels, on the other hand students prefer activities based on visual skills more, and activity-based teaching triggers students to be more active and eager to participate in group work through the process of values acquisition.

Etik Beyan / Ethical Statement: Bu çalışmanın hazırlanma sürecinde bilimsel ve etik ilkelere uyulduğu ve yararlanılan tüm çalışmaların kaynakçada belirtildiği beyan olunur. / It is declared that scientific and ethical principles have been followed while carrying out and writing this study and that all the sources used have been properly cited.

Finansman / Funding: Yazarlar, bu araştırmayı desteklemek için herhangi bir dış fon almadıklarını kabul ederler. / The authors acknowledge that they recevied no external funding in support of this research.

Yazar (lar) / Author (s): Yasemin ALTINSOY, Zeynep BAŞÇI NAMLI 
Yazar Katkıları / Author Contributions: Yasemin ALTINSOY (\%50), Zeynep BAŞÇI NAMLI (\%50)

Çıkar Çatışması / Competing Interests: Yazarlar, çıkar çatışması olmadığını beyan ederler. / The authors declare that they have no competing interests. 